\title{
Orofacial Findings and Dental Management of a Child with Williams Syndrome
}

Luciana Pereira ${ }^{a}$, Daniela Novaes Soares ${ }^{a}$, Rafael de Lima Pedro ${ }^{a}$, Tatiana Kelly da Silva Fidalgo ${ }^{a}$, Marcelo Castro Costa ${ }^{a}$, Gloria Fernanda Barbosa de Araújo Castro ${ }^{a}$

\begin{abstract}
Williams syndrome (WS) is a multisystem, congenital and panethnic disorder characterized by developmental and physical abnormalities. Developmental abnormalities in dentition are frequently observed in various patients with craniofacial syndromes, however there are a few reports regarding dental management in patients with WS. The aim of the present report is to describe the case of a 6 -year-old child with characteristic facial features of WS with remarkable orofacial findings and the ensuing dental management. An intraoral examination revealed a mixed dentition period, with tooth agenesis and caries requiring treatment such as extraction, restoration and fluoride application. The dental treatment was carried out under local anesthesia and was completed successfully. Since then clinical and radiographic evaluations have been conducted periodically.
\end{abstract}

Key words: Williams syndrome; Agenesis; Children

\section{Manejo e características orofaciais de crianças portadoras da síndrome de Williams}

\section{RESUMO}

A síndrome de Williams (SW) é uma doença congênita e pan-étnica caracterizada por anomalias do desenvolvimento e físicos. O desenvolvimento de anormalidades em dentição são frequentemente observadas em vários pacientes com síndromes craniofaciais, no entanto, existem poucos relatos sobre o manejo odontológico de pacientes com SW. O objetivo do presente relato é descrever as condutas de atendimento do caso de uma criança de 6 anos de idade, com traços faciais característicos de SW com características orofaciais relacionadas à SW. O exame bucal revelou uma dentição mista, com agenesia dentária e cáries que exigem tratamento, como extração, restauração e aplicação de flúor. O tratamento odontológico foi realizado sob anestesia local e foi concluída com êxito. Desde então, as avaliações clínicas e radiográficas têm sido realizadas periodicamente. Palavras-chave: Síndrome de Williams; Agenesia; Crianças. a School of Dentistry, Federal University of Rio de Janeiro (UFRJ), Rio de Janeiro, Brazil 


\section{INTRODUCTION}

Williams syndrome (WS) is a rare multisystem disorder, first described by Williams et al., [1] that is caused by the deletion of 26 contiguous genes, including elastin (ELN) on chromosome 7q11.23 [2]. This genomic disorder with an incidence of 1: 7,500 [3] is mainly characterized by: connective tissue abnormalities affecting the cardiovascular organs, dysmorphic facial features known as "elfin face", a unique cognitive profile, short stature, behavior characteristics and neurological abnormalities [4].

The diagnosis of WS is seldom considered in infants and young children due to the lack of cardinal WS findings, such as of supravalvular aortic stenosis (SVAS) and/or hypercalcemia. Children are usually diagnosed later when developmental delay and/or growth retardation appear [5].

Developmental anomalies of the dentition of WS patients are frequently observed although only a few reports regarding these characteristics and the dental management have ever been published. Changes in number, size, shape, and position of teeth, causing disturbances in dental occlusion, oral function and orofacial esthetics can be found in these patients and may complicate dental treatment [6]. The present report describes the orofacial findings and dental management of a young child diagnosed with Williams syndrome.

\section{CASE REPORT}

A 6-year-old boy diagnosed with WS was referred to the Pediatric Dentistry Clinic with the chief complaint of dental caries. During anamnesis his mother related that his prenatal period and delivery were uneventful. His parents were health and had no medical history of suspected WS. He was hospitalized with bronchitis at the age of 6 months. In addition, he also revealed cognitive deficits and development delay (at school). According to geneticist, the diagnosis of SW was based on characteristic facial features and a cognitive profile.

The clinical examination revealed a short stature and dysmorphic facial features (Figure 1). The intraoral examination revealed a mixed dentition period; anterior open bite, caries, which required extractions or restorations and interceptive orthodontic treatment for malocclusion and fluoride application (Figure 2A-B). Radiographic examination revealed agenesis of the permanent maxillary left lateral incisor and of the permanent mandibular lateral incisors; deviant shaped of the permanent maxillary central incisors and; excessive interdental spaces and malocclusion traits (Figure 3A-B). Also, radiolucency suggestive of caries beneath the previous restorations was observed.

Owing to good cooperation it was decided to carry out the dental treatment under local anesthesia without sedation. Medical agreement for the procedure was obtained. Dental treatment was successfully completed regarding restorations and extractions (Figure 4A-B). The patient is followed up for clinical and radiographic evaluation quarterly to avoid new caries and to decide the most opportune time to apply an orthodontic apparatus.

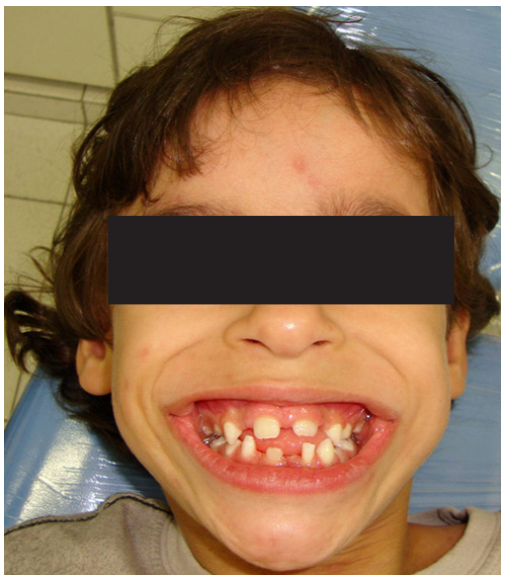

Figure 1. Typical facial appearance of a Williams syndrome patient showing wide mouth, with long philtrum and thick lower lips.

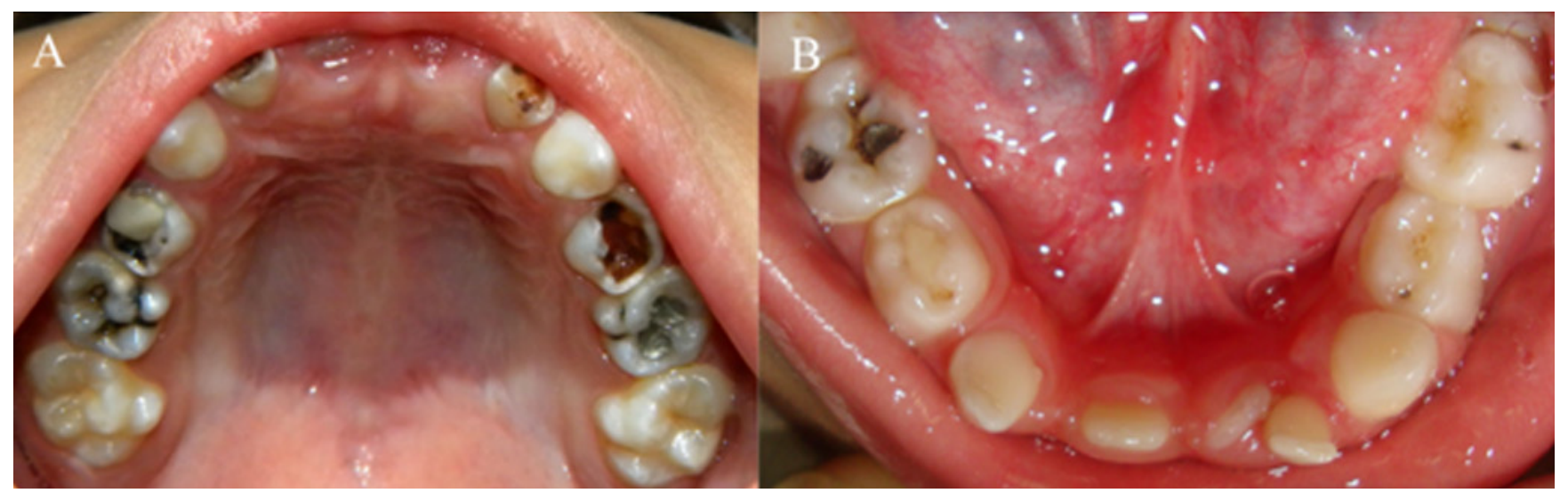

Figure 2. A - Mixed dentition period, required extraction of second maxillary right lateral incisor and second maxillary left lateral incisor, restoration of first maxillary right molar, second maxillary right molar, first maxillary left molar and, second maxillary left molar. B - Mixed dentition period, required extraction of first mandibular left central incisor and restoration of second mandibular right molar. 


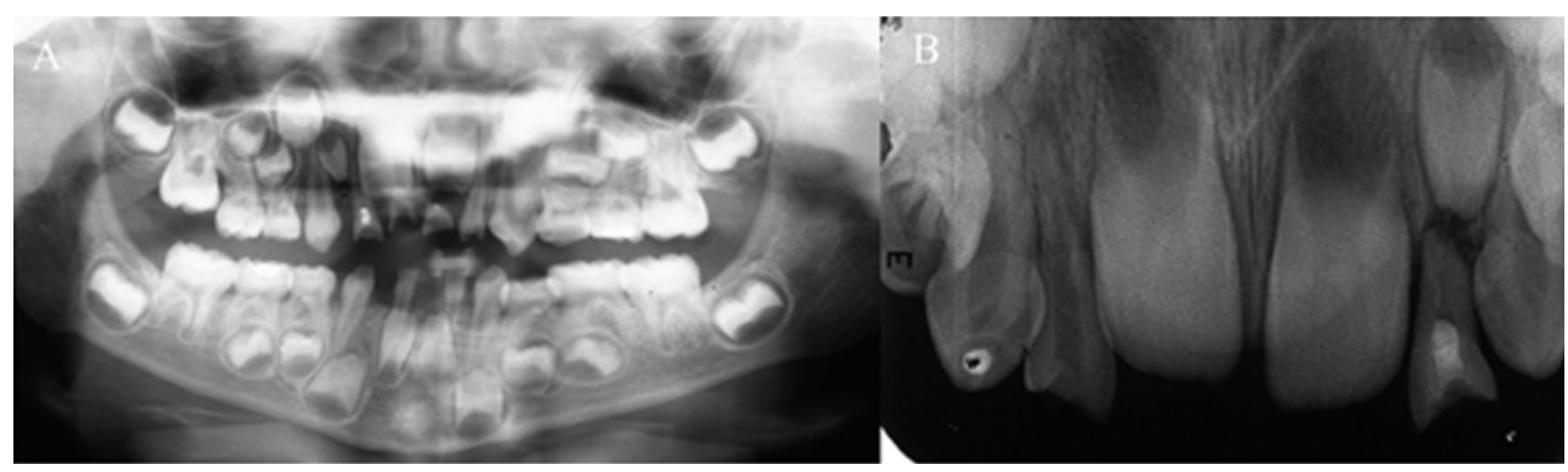

Figure 3. A - Panoramic radiography revealed agenesis of the permanent maxillary left lateral incisor and of the permanent mandibular lateral incisors, excessive interdental spaces and malocclusion traits. B - Intraoral radiograph revealed a deviant shape of the permanent maxillary central incisors.

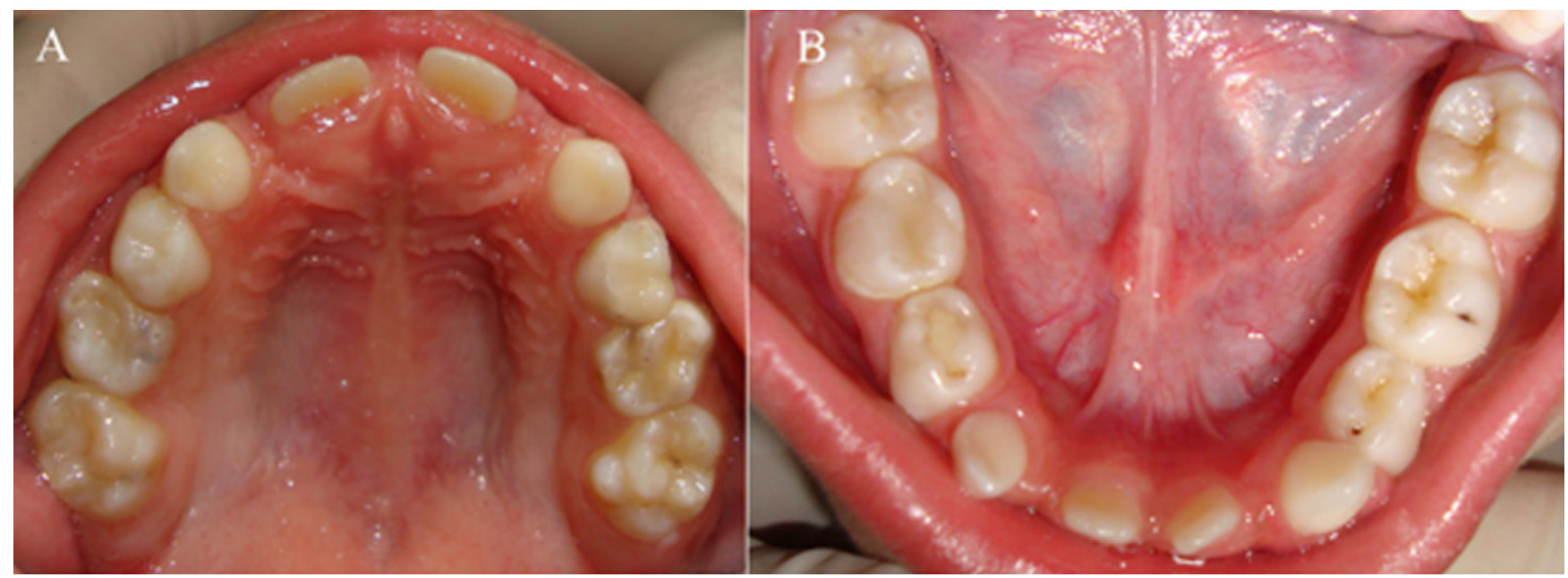

Figure 4. A - Dental treatment was successfully completed in maxilla. B - Dental treatment was successfully completed in mandible.

\section{DISCUSSION}

The Williams syndrome has no sex, race, or ethnic predilection, and some cases result from a spontaneous new gene deletion, but few have arisen through parent-to-child transmission. For healthy parents who have a child with this disorder the risk of recurrence is usually low, but somatic cell mosaicism remains a theoretical possibility [7]. Genetic counseling is described by Morris [2].

WS is a multisystem, congenital and panethnic disorder characterized by a number of developmental and physical abnormalities [1]. Beuren, Apitz et al [8] described the syndrome previously reported by Willians et al and expanded the phenotype including other congenital anomalies such as dental malformations. Although our patient did not have, at the time of this report, the cardiac features of the syndrome [5], he had the typical dental findings reported by Oncag et al. [9] such as tooth abnormalities, dental caries, excessive interdental spaces and malocclusion traits. In addition, our case is the first report that shows multiple agenesis.
General anesthesia is usually recommended for dental treatment in an attempt to avoid anxiety caused by the procedure and for behavioral control in patients with extensive dental needs. Also, this procedure is considered to be safer for the patient and may prevent cardiovascular exacerbation, since conventional dental therapy could be very difficult due to the patient's mental retardation $[4,10]$. In the present case, it was possible to treat the patient under local anesthesia using conventional behavior management since the patient was cooperative and did not present any cardiac abnormality. According to the mother, there were attempts to treat the patient on previous occasions, without success, due to a lack of cooperation, which no doubt collaborated for the present oral health status. The patient had never been referred to specialized services before.

Social isolation, distractibility, inflexibility, and ritualism may be described as autistic features. Children with WS are 4 times more likely to have attention deficit and hyperactivity disorder, approximately $80 \%$ of these patients exhibit generalized anxiety disorder $[11,12]$. However, it 
was possible to establish a satisfactory communication with the patient which enable us to carry out a less invasive and less expensive intervention.

The treatment of caries activity and the control of risk is important because dental caries and subsequent periodontitis could lead to other focal infections [4] mainly in patients with systemic disorders. Therefore, a periodic monitoring, not only by the dentist but by the entire multidisciplinary team must be a priority for these patients.

\section{CONCLUSION}

Facial alterations and dental anomalies are common in children with WS, thus it is imperative that the dentist recognizes the oral findings and is able to contribute to the successful management of these patients. Child dental care including restorative treatments and nutrition counseling among others are important for maximizing the quality of life of patients with WS. The present case report showed that it was possible to manage this patient and reestablish oral health.

\section{REFERENCES}

1. Williams JC, Barratt-Boyes BG, Lowe JB. Supravalvular aortic stenosis. Circulation. 1961:24:1311-8
2. Morris CA. Introduction: Williams syndrome. Am J Med Genet C Semin Med Genet. 2010;154:203-8

3. Stromme P, Bjornstad PG, Ramstad K. Prevalence estimation of Williams syndrome. J Child Neurol. 2002;17:269-71.

4. Kohase H, Wakita R, Doi S, Umino M. General anesthesia for dental treatment in a Williams syndrome patient with severe aortic and pulmonary valve stenosis: suspected episode of postoperatively malignant hyperthermia. Oral Surg Oral Med Oral Pathol Oral Radiol Endod. 2007; 104:e17-20

5. Morris CA, Demsey SA, Leonard CO, Dilts C, Blackburn BL. Natural history of Williams syndrome: physical characteristics. J Pediatr. 1988;113: 318-26.

6. Axelsson S, Bjornland T, Kjaer I, Heiberg A, Storhaug K. Dental characteristics in Williams syndrome: a clinical and radiographic evaluation. Acta Odontol Scand. 2003 ;61:129-36.

7. Lashkari A, Smith AK, Graham JM, Jr. Williams-Beuren syndrome an update and review for the primary physician. Clin Pediatr (Phila). 1999;38:189-208

8. Beuren AJ, Apitz J, Harmjanz D. Supravalvular aortic stenosis in association with mental retardation and a certain facial appearance. Circulation. 1962;261235-40

9. Oncag A, Gunbay S, Parlar A. Williams syndrome. J Clin Pediatr Dent. 1995;19:301-4.

10. Moskovitz M, Brener D, Faibis S, Peretz B. Medical considerations in denta treatment of children with Williams syndrome. Oral Surg Oral Med Oral Pathol Oral Radiol Endod. 2005;99:573-80.

11. American Academy of Pediatrics: Health care supervision for children with Williams syndrome. Pediatrics. 2001;107:1192-204.

12. Gosch A, Pankau R. Social-emotional and behavioral adjustment in children with Williams-Beuren syndrome. Am J Med Genet. 1994;53:335-9 